\title{
Using Key "Blue Ocean" Tools for Strategy Rethinking of a SME: A Case from the Bulgarian Knitwear Industry
}

\author{
Emil Papazov ${ }^{1}$, Lyudmila Mihaylova ${ }^{2}$ \\ ${ }^{1}$ University of National and World Economy - Sofia \\ ${ }^{1,2}$ University of Ruse
}

\begin{abstract}
The purpose of the article is to explore opportunities for rethinking the strategy of small and medium enterprises (SMEs) using the "Blue Ocean" concept and its inherent value innovation paradigm as an alternative to the traditional competitive strategy rationale. The paper also highlights important aspects of analytical tools of a relatively less known practice for Bulgaria, such as the "Strategy Canvas", the "Four Actions Framework", the "Eliminate-Reduce-Raise-Create Grid" and the "Six Paths Framework", and shows how to apply them when analysing and creating a new and uncontested market space. Special attention is paid to the possibilities concerning the practical use of the described tools in a leading SME from the Bulgarian knitwear industry.
\end{abstract}

Keywords - "Blue Ocean" strategy, small and medium enterprise (SME), strategic management, value innovation.

\section{INTRODUCTION}

In a turbulent environment, the necessity for a thorough understanding of the situation with a subsequent and adequate change in strategy reinforces the need to provide specific techniques for strategic analysis and planning. The efforts in this direction are now aimed at covering not only foreseeable, but also unexplored market space, revealing additional growth prospects. Precisely with view to meet these needs the strategic paradigm "Blue Ocean" has been recently launched (by the INSEAD professors W. Chan Kim and R. Mauborgne; a detailed summary of their main ideas can be found in (Kim \& Mauborgne, 2005a)) and is now well received in countries with developed market economy.

However, the "Blue Ocean" strategy is still little known and rarely used for business purposes in Bulgaria. While the principles of the strategy are relatively easy to grasp, some of the applied tools need further clarification and comments in order to be used effectively in the management practice. There are also some organisational barriers that traditionally go along with the introduction of new management approaches.

A good and realistic "advertisement" of the opportunities accompanying the implementation of the "Blue Ocean" paradigm will most likely provoke the business to show interest and endeavour to start coping with this profound management innovation. In this study, the target group is SMEs, because the small business is the one urgently needing proper management tools adequate to its target orientation and resource capabilities. The investigation focuses on companies from the Bulgarian knitwear industry. The concrete target is a knitwear company chosen among 10 leading SMEs from a traditional sector of the Bulgarian economy. The aim of this paper is to present the possibilities of using key instruments of the "Blue Ocean" concept to rethink strategies pursued by SMEs in a highly unsteady environment.

\section{THE URGE TO RETHINK STRATEGY OF SMES}

The strategic management of SMEs possesses certain characteristics. Part of the specifics is related to the fact that a majority of SMEs (as opposed to large companies) operate on limited and goal-oriented markets, which requires the identification of the specific needs of a relatively small group of customers and their subsequent satisfaction. This prevents SMEs to benefit from the effects typical of large companies (e.g. economies of scale), which under fierce competition leads to limiting the growth of the business and its effectiveness.

Additionally, in shaping their strategies SMEs can hardly rely on approaches and tools specifically designed for their strategic needs, since normally such instruments have been created with view to the requirements of large companies [There are few attempts to create special or adapt existing tools for strategic management needs of SMEs. Among the most popular appear the "Relative Advantage Matrix" (RAM), the "Strategic Position and Action Evaluation" (SPACE) matrix, the "Growth-Effectiveness Matrix" and other similar portfolio techniques. The notion of the RAM matrix model is to help SMEs to look for competitive advantages in the context of the environment. The SPACE matrix model can be considered a complement and extension of the RAM matrix model with the aim to give rise to a concern in entrepreneurs and managers for a more flexible strategic response to environmental conditions, taking into account the competitive advantages or disadvantages of the small enterprise. GEM is an adapted version of the famous "Growth-Share" model of the Boston Consulting Group, through which the SMEs are given a chance to conduct analyses similar to those of the original model. For further details, see (David, 2011; Papazov \& Mihaylova, 2012a; Zafirova, 2011; Papazov \& Mihaylova, 2012b; Papazov \& Mihaylova, 2009)]. Being often unable to use them, SMEs content themselves to formulating "lines of behaviour" instead of strategies (Todorov, 2011).

When small and mid-sized businesses develop strategies, the efforts are focused primarily on coping with the competition. 
An analysis of environment is made to justify the choice of a strategic position associated with one of the two alternatives low cost or differentiation (Papazov, 2012), within the borders of the whole market or a part of it (Papazov \& Mihaylova, 2011; Siegemund, 2008), and to determine the target value of the market share, which will be pursued.

But to what extent SMEs with such a strategic mind-set are able to resist the expanding competition and maintain an optimal relationship between the buyer value and costs? No matter how well competitive strategies are conceptualized, trends in the economy show an increasing demand for a new and uncontested market space associated with new ways of enhancing of specific customer needs. In the economic theory such an insight is associated with the notion of "value innovation" that lies at the heart of the "Blue Ocean" strategy (Kim \& Mauborgne, 2005b).

A value innovation is normally connected with the flow of two parallel processes: a buyer value increase through raising and/or creating elements, which the industry has never offered so far, and a cost reduction through eliminating or reducing of outdated factors, across which the companies usually compete. Over time, costs are further reduced due to economies of scale, which in turn follows the created higher consumer value and the subsequent increased sales. Normally, value innovation is created in the interaction zone between cost reduction and buyer value increase (Fig. 1).

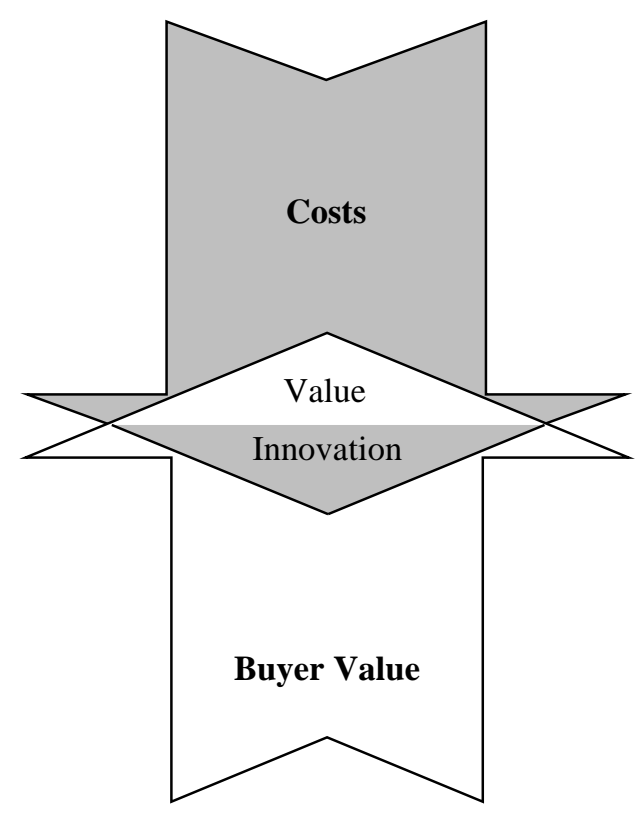

Fig. 1. Value Innovation zone, Source: Adapted from (Kim \& Mauborgne, 2005a).

Based on the value innovation notion, the possibility of rethinking the strategic orientation of companies shifts parallel to additional value creation through differentiation and at the same time to cost optimization based on elimination or reduction of elements offering little or no value to consumers (Mislyashki, 2010; Aulet, 2013). Acting in this way, a growth in value for both the enterprise and/or customers of the targeted market is achieved, seeking long-term effects. Therefore, such a strategic vision can be extremely successful in SMEs showing a typical orientation to limited and goal-oriented markets.

The focus of this paper is oriented toward exploring opportunities for strategic decision rationale for SMEs based on the value innovation as an alternative to the traditional competitive strategy thinking. The paper also highlights important aspects of analytical tools of a relatively less known practice for Bulgaria, such as the "Strategy Canvas", the "Four Actions Framework", the "Eliminate-Reduce-Raise-Create Grid" and the "Six Paths Framework", used for analysing and working out of a "Blue Ocean" strategy. Special attention is also paid to the possibilities concerning the practical use of the described tools in a leading SME from the Bulgarian knitwear industry.

\section{III. "Blue OCEAN” STRATEGIC PLANNING TOOLS APPLICABLE TO SMES}

Recently, there has been an increased interest in the application of different methods for analysis and planning of the activities of SMEs. The interest is evoked by the fact that a number of studies proved a correlation between using adequate planning tools and achieving good financial performance (Ciemleja \& Lace, 2011; Bistrova \& Lace, 2012). In view of this, some of the "Blue Ocean" strategy tools will be presented shortly.

The "Strategy Canvas" is considered a major diagnostic and action framework tool belonging to the "Blue Ocean" strategy. It shows the present business situation in a known market space and allows understanding the investment intentions of competition and the factors shaping the industry development (Sheehan \& Vaidyanathan, 2009).

The "Strategy Canvas" is situated between two axes a horizontal axis and a vertical one. On the horizontal axis the range of factors, which the industry is competing with and investing in, is represented. The offering level that customers receive across all these basic competing factors is represented on the vertical axis. The level range is between low and high. A high factor level means that the offering level buyers receive is in excess; hence, the company invests more in this factor. A higher level is associated with a higher price and vice versa.

The main component of the "Strategy Canvas" is the "Value Curve". It is a graphical representation of the relative performance of a company while keeping with the industry factors of rivalry.

It is recommended to use the "Strategy Canvas" together with another analytical tool called "Four Actions Framework". It aims to reconstruct buyer value elements and plan new value curves by breaking the trade-off between differentiation and low cost.

The "Four Actions Framework" tries to find an answer to the following questions (Kim \& Mauborgne, 2005a):

- What factors can be eliminated that the industry has taken for granted? The answer is related to removal of factors, with which companies of the respective industry (sector) compete. Usually these factors are considered traditional, although they no longer possess the previous value or 
even have a lower one. Sometimes, what the customers used to value has radically changed, but companies take no action or even do not notice the change.

- What factors can be reduced well below the industry standard? The answer to this question is linked to the aspect whether products and services lose their meaning in the attempt to offer the same products and services comparable to those of competitors. Often companies supply customers with more than necessary, increasing costs and reducing profits at the same time.

- What factors can be raised well above the industry standard? The idea is to identify and remove the trade-offs that customers are forced to make when buying a product or service and to offer them better solutions.

- What factors can be created that the industry has never offered? To answer this question, new sources of value to customers are explored, thus creating new demand and changing the price structure of the industry (sector).

Finding answers to the first two questions explains the mechanism for cost reduction in comparison with those of the competitors. Answers to the latter two questions show how a value added to the consumer is formed and a new demand created.

In fact, the implementation of the "Four Actions Framework" and the "Strategy Canvas" is complementary to the third alternative strategic tool called "Eliminate-Reduce-RaiseCreate Grid". Through this matrix, the companies try to answer the key questions of the "Four Actions Framework" and draw a new value curve. As it has already been explained, the value curve is related to the focus of the company on certain value creating factors and helps distinguish them from the general profile of the competitors in the industry. The distinction is namely achieved through four steps: eliminate, reduce, enhance and create value. The cost curve also contributes to the creation of company's mission indicating as basic elements those related to value growth.

Studies show that as an alternative strategic tool the presented matrix has some major advantages that can be used in SMEs (Burke, van Stel \& Thurik, 2009). They can be summarised as follows:

- With the development of the matrix, managers are encouraged to simultaneously look for ways to differentiate products (services) and reduce the costs for their creation without making compromises.

- After conducting analyses with the help of the abovementioned tool, one can quickly ascertain the fact that managers or owners of SMEs turn their efforts mainly to activities such as "raise" and "create". This normally leads to a significant increase of costs, which over time brings more to losses than gains - a situation that seems to be a common practice in SMEs.

- The matrix can be relatively easy understood by managers or owners of SMEs, which in turn insures a high degree of commitment in the process of its implementation.

- The preparation of the "Eliminate-Reduce-Raise-Create Grid" is a challenging task that makes managers and owners of SMEs accurately assess the impact of each factor and identify a full range of assumptions that are made unconsciously in the competitive struggle.

Another analytical model applicable to SMEs for developing a "Blue Ocean" strategy is the "Six Paths Framework". With its help, the SMEs should be able to examine more closely the alternative businesses (industries), the strategic groups and the customer groups, the proposals for additional products and services, the functional-emotional orientation of the industry and even the temporal development. This will give a clearer view of how businesses can break up market boundaries and find "Blue Oceans".

Each of these six paths has its own characteristics and can be described as follows (Kim \& Mauborgne, 2005a):

- The first path: looking across alternative industries (products). The focus is placed on analysing alternative products and services and namely those, which have different functions and forms but are subject to the same goal.

- The second path: looking across strategic groups within industries (branches). The analysis is oriented towards a group of companies in the same industry, which follow the same strategy. Some similarities can stem from the cost side of the way the companies are performing.

- The third path: looking across the chain of buyers. The chain of buyers includes not only the direct purchasers, but also those who can influence the consumer choice decisions. Clients for a medicine constitute a good example: they are direct purchasers in the drug stores, but their decisions are influenced by doctors.

- The fourth path: looking across complementary products and services. The idea is to bear in mind that products and services have potential untapped value. In this connection, it is important that SMEs explore what happens before, during and after the use of their products or services.

- The fifth path: looking across functional or emotional appeal to buyers. In the effort to create a functional and emotional appeal of its products, companies often find new market space. Emotionally oriented companies offer usually features that increase cost without improving functionality. Removal of these extras could create a simpler, inexpensive and lower cost product that customers would welcome.

- The sixth path: looking across time. The analysis focuses on the trends in value change - from present to future periods, and more specifically to the factors that determine it.

Building on the sixth paths for developing a "Blue Ocean" strategy, SMEs can apply an alternative approach to strategic planning based on the four steps of visualizing strategy (Kim \& Mauborgne, 2002). These steps provide practical direction for alternative design and visualization of a strategy and some of them have been used for the purpose of the strategic planning case study conducted among knitwear producing SMEs in Bulgaria:

- The first step of visualizing a strategy: the visual awakening. The visual awakening is related to the comparison of a business with that of its competitors by 
creating an actual strategic chart followed by identification of weaknesses of the strategy, which need to be changed.

- The second step of visualizing a strategy: the visual exploration. The visual exploration is related to the practical implementation of the "Six Paths" technique emphasizing alternative products and factors that need modification.

- The third step of visualizing a strategy: the visual strategy fair. The visual strategy fair is connected to the strategic plotting diagram based on observations made for the industry, as well as the strategic alternative charts based on customer reviews, customers of competitors and nonclients of the company.

- The fourth step of visualizing a strategy: the visual communication. The visual communication describes the strategic profile of a company (concrete SME in our case) before and after the study and identifies moves aimed at implementing of new strategic intents.

\section{APPLYING "BLUE OCEAN" ANALYTICAL TOOLS IN SMES FROM THE BULGARIAN KNITWEAR INDUSTRY}

The "Blue Ocean" tools, analysed in the previous paragraph, have been applied in the process of strategy rethinking of SMEs manufacturing knitwear in South Central Planning Region (SCPR) of Bulgaria. The territorial restraint enables a more thorough study of the statistical population, since about $90 \%$ of the companies of that type are concentrated there. The socioeconomic structure of the industry shows that the share of large firms is about $5 \%$, i.e., the sector is concentrated in SMEs. The largest group consists of small enterprises with employees up to 49 people. The capital of the companies is mostly nationally owned. Technologically, the companies do not differ much from one another (Milev, 2010; Papazov \& Milev, 2005; Papazov \& Mihaylova, 2012b).

The exposition is mainly focused on a case study, but prior to it a preliminary analysis of ten leading SMEs manufacturing knitwear in the South Central Planning Region (SCPR) of Bulgaria was conducted. The data gathering was performed in the period of 2013-2014 by a preliminary plan. These SMEs confirmed in advance their readiness for a discussion on the possibilities to apply the "Blue Ocean" concept for strategic purposes.

Because of the novelty of the problem for the Bulgarian practice, the study had a relatively limited character. The aim was to approbate an alternative approach to strategic planning through appropriate modern tools [The case approach has been used in other studies on the possibility of application of the
"Blue Ocean" strategy with limited research opportunities and new problems of the surveyed sites. For details, see (Papazov \& Mihaylova, 2009)]. SMEs that shared the idea of strategic planning through the "Blue Ocean" concept were interviewed about their experience in strategic management and especially about the applied competitive strategy, the advantages of their products and the opportunities for possible innovations.

Table I summarises the results of the preliminary research analysis of the ten SMEs manufacturing knitwear concerning the factors of competition and the average level of assuring the supply by the industry. The factors mentioned below and derived from the studied group of SMEs manufacturing knitted fabrics are considered so far essential.

TABLE I

PRELIMINARy RESEARCH RESUltS OF THE TEN LEADING KNITWEAR MANUFACTURERS

\begin{tabular}{|l|c|}
\hline \multicolumn{1}{|c|}{$\begin{array}{c}\text { Factors of competition in the } \\
\text { Bulgarian knitwear industry }\end{array}$} & $\begin{array}{c}\text { Average level of supply that } \\
\text { customers receive, grading } \\
\text { from 1 (low) to 10 (high), } \\
\text { Rank }\end{array}$ \\
\hline Price & 4 \\
\hline Design & 3 \\
\hline Sustainability to heat & 6 \\
\hline Using lycra & 5 \\
\hline Production of patterns and samples & 5 \\
\hline Variety of fabrics & 3 \\
\hline Using natural materials & 7 \\
\hline Small series production & 4 \\
\hline Deadline for carrying out the order & 5 \\
\hline
\end{tabular}

These factors were identified by studied SMEs (as the first step) and their evaluation was made (as the second step). The data were used to construct a "Strategy Canvas" for the Bulgarian knitwear industry from the SCPR (Fig. 2).

Based on the gathered and analysed information, a SME with a full production cycle for manufacturing knitted fabrics [On insistence of the company's management the name of the firm will not be disclosed] was chosen for outlining the main strategic development aspects in accordance with the ideas of the "Blue Ocean" concept. The strategic intentions of the targeted company are summarised with the help of the "Four Actions Framework" using its specific dimensions:

- Elimination of the element "Production of Samples and Patterns". Nowadays, this production loses its value and is a costly activity that bears no significant benefits to users of knitted fabrics. 


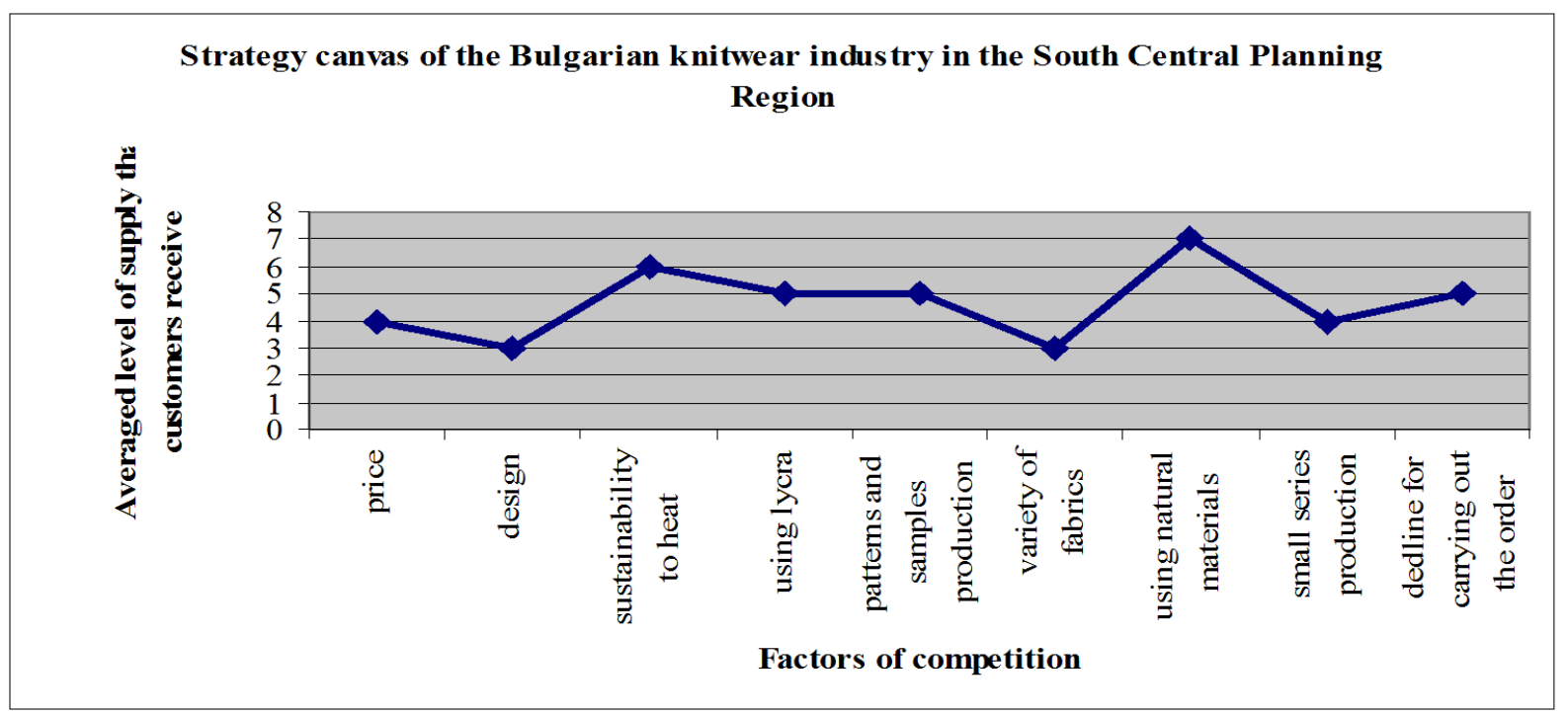

Fig. 2. The "Strategy Canvas" for a part of the Bulgarian knitwear industry.

- Reduction well below the Bulgarian knitwear industry standard of the element "Fabrics sustainability to heat, variety of fabrics production and using natural materials". The study shows that the offering of these items to customers increases the production costs more than necessary and without adding consumer value or increasing the demand for these commodities.

- Raising the level of lycra usage in fabrics well above the Bulgarian knitwear industry standards; manufacturing of more expensive fabrics replacing the low-cost ones and delivery of orders in small production series on time. The research of the company in recent years shows an increasing demand from customers of knitted fabrics with elastomeric thread, but this exceeds the supply of such fabrics. Therefore, the investigated company plans to eliminate the weaknesses, for which customers make compromises when purchasing fabrics, and to increase supply of the desired items above the industry average level.

- Creation of sun-sustainable fabrics for awnings, umbrellas and flags, working out of fabrics in accordance with customer preferences, virtual patterns and models, which the industry does not offer. With similar moves the company's management is looking for new sources of value for customers, creating a new demand (e.g. for preparation of national flags, specialised sportswear, etc.) and a planned change in the pricing strategy.

In addition to the "Four Actions" framework, the "EliminateReduce-Raise-Create Grid" has been worked out for the studied SME in Bulgaria (Table II).

Table II presents the elements, which the industry will be creating or struggling for, and those which should be reduced and eliminated.
TABLE II

The “Eliminate-Reduce-RAise-CREATE GRID” FOR THE STUdiEd SME

\begin{tabular}{|l|l|}
\hline $\begin{array}{l}\text { Eliminate } \\
\text { Production of samples and } \\
\text { patterns }\end{array}$ & $\begin{array}{l}\text { Raise } \\
\text { Using lycra in fabrics (knitwear) } \\
\text { manufacturing } \\
\text { Production of dear fabrics (knitwear) } \\
\text { replacing the low-cost ones } \\
\text { Just-in-time delivery of orders and } \\
\text { small series production }\end{array}$ \\
\hline $\begin{array}{l}\text { Reduce } \\
\text { Vabrics sustainable to heat } \\
\text { Using natural materials }\end{array}$ & $\begin{array}{l}\text { Create } \\
\text { Sun-sustainability fabrics for awnings, } \\
\text { umbrellas and flags }\end{array}$ \\
& $\begin{array}{l}\text { Virtual patterns and models } \\
\text { Working out of fabrics preferred by } \\
\text { customers }\end{array}$ \\
\hline
\end{tabular}

The case company has decided to eliminate the production of samples and patterns of fabric - a factor that has been considered traditional and its significance has not been called into question for years. The analysis shows that the production of samples is an expensive item in the knitwear production and over time loses its value from the user perspective, especially in the international trade, where the ordering and sending of samples have been seen as extra costly. Furthermore, the sample does not always give a good impression of the offered product, its properties and applications to the customer. An alternative for the company is to create virtual samples and patterns. They cost several times less than the traditional samples and patterns, allowing the clients a quick access to them with virtual testing of their properties and applications. Thanks to them and to available software, the development of materials on request and the simulation testing of the sunsustainability of the fabric are made possible. By doing so, the company is seeking a way to abandon the traditional industry constraints. 


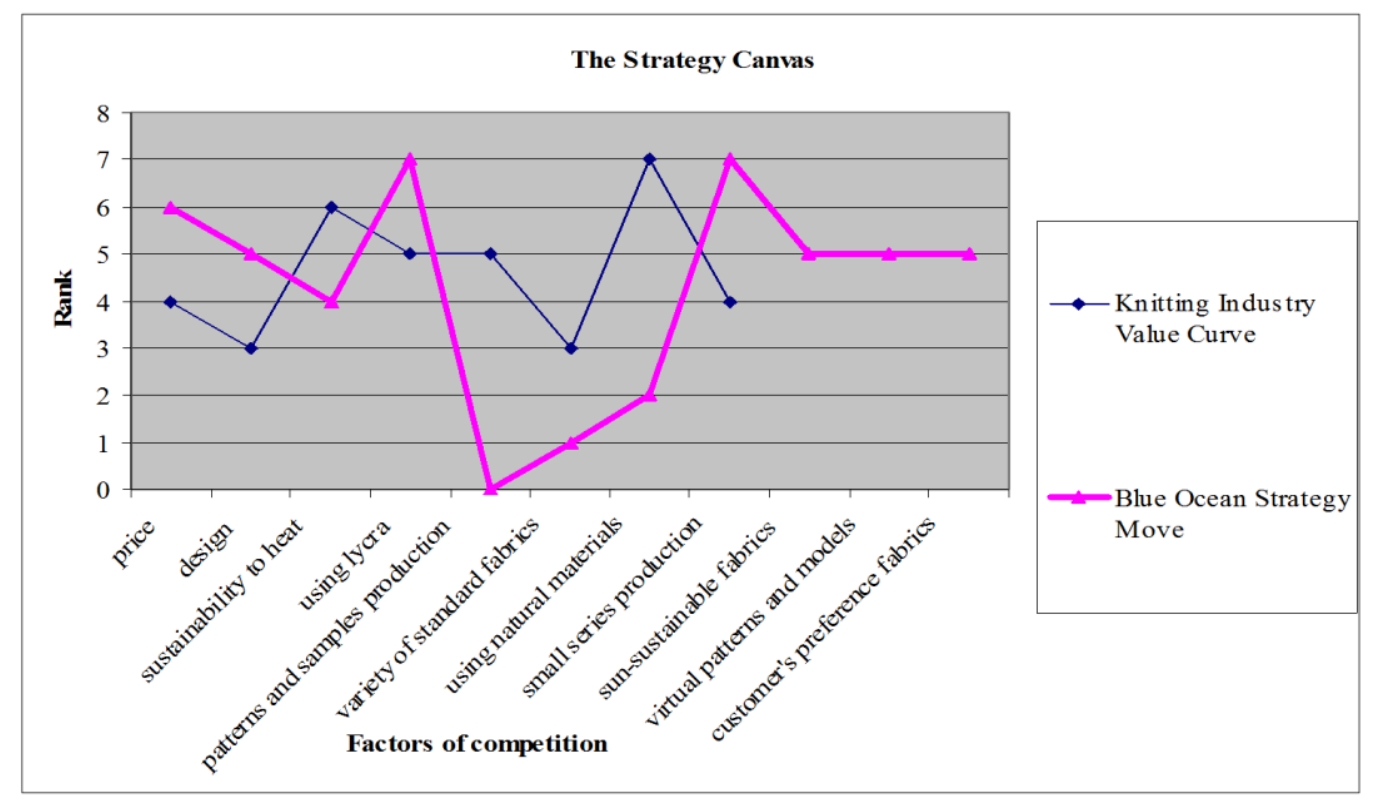

Fig. 3. A possible "Blue Ocean" strategy move for the studied SME.

One possibility in this direction is associated with the specific paths for development of the corporate strategy based on the "Blue Ocean" concept. The studied SME is orientated to three main paths (of the "Six Paths Framework"), looking across alternative industries, strategic groups within industries and complementary products / services. The limitation is necessary because of the lack of experience in using the tools of the "Blue Ocean" concept, as well as funds. These three paths are practically orientated to strategy development of the studied SME from the knitwear manufacturing industry:

- The path: looking across alternative industries. The focus is placed on analysing the possibilities of the software for sampling and modelling of knitwear, which fulfil the same purpose as the traditional samples or patterns in presenting the properties of the fabric and the possibilities for its use by customers.

- The path: looking across strategic groups within industries. Emphasis is placed on the addition of lycra for improved elasticity, combined with a reduction of the heat resistance and the use of natural materials for manufacturing of knitted fabric (e.g. the creation of an innovative material with properties from the group of polyesters with lycra). This will attract new customers, including manufacturers of specialized sportswear for water sports.

- The path: looking across complementary products and services. The company is considering the idea to offer sewing patterns for knitwear manufacturing following an individual customer's order, including desired and stated fabrics at a preferential price.

These three main paths grip the attention of SMEs' managers to the alternative ways of strategy formulation in the knitwear sector. Applying analytical tools of the "Blue Ocean" strategic thinking allows for the outlining of the "Strategy Canvas" and the expected SME's "Value Curve", which represents a possible "Blue Ocean" strategy move (Fig. 3).

The value curve of the studied SME manufacturing knitwear shows obvious differences from the other SME strategies, especially with regard to traditional patterns of production and natural materials usage in knitted fabrics manufacture. This gives a reason to believe that the planned strategic movement of the studied SME has a commercial potential for future development. The result verification was performed by the leading SME.

It is important to note one more fact that is partly due to the size of the studied SME and its production specifics (Kim \& Mauborgne, 2014). Its innovation activity is not only the task of one manager, but should also engage the majority of the personnel, i.e., the head of production department, sales manager, logistics manager, chief accountant, technologists, designers, software specialists, etc. This will keep people committed and overcome the employees' disengagement from the process of implementing a new "Blue Ocean" strategy.

\section{CONCLUSION}

The performed analysis represents an attempt to explore possibilities for application of an alternative, "Blue Ocean" tools for rethinking strategy of SMEs. The paper has presented some of the tools developed by the "Blue Ocean" strategic concept and the possibility for their usage for practical purposes. The idea is to provide SMEs with an opportunity to outline a sophisticated strategy.

Most of the "Blue Ocean" strategic instruments can be applied successfully to SMEs without modifications. Other techniques seem inappropriate because of the information requirements they stipulate (Papazov \& Mihaylova, 2010). As a whole, the usage of ideas connected with this new way of strategic thinking seems reasonable. 


\section{REFERENCES}

Aulet, B. (2013). Disciplined Entrepreneurship. 24 Steps to a Successful Startup. Hoboken, New Jersey, USA: John Wiley\& Sons, Inc.

Bistrova, J. \& Lace, N. (2012). Trade-off between Investor's Short- and Longterm Goals. Economics and Business, 22, 23-29.

Bourletidis, D. (2014). The Strategic Model of Innovation Clusters: Implementation of Blue Ocean Strategy in a typical Greek Region. Procedia - Social and Behavioural Sciences, 148, 645-652. http://dx.doi.org/10.1016/j.sbspro.2014.07.093

Burke, A., van Stel, A. \& Thurik, R. (2009). Blue Ocean Versus Competitive Strategy: Theory and Evidence (May 29, 2009). ERIM Report Series Reference No. ERS-2009-030-ORG. Retrieved July, 15, 2015 from http://ssrn.com/abstract=2024822

Ciemleja, G. \& Lace, N. (2011). The Model of Sustainable Performance of Small and Medium-sized Enterprise. Engineering economics, 22(5), 501-509. http://dx.doi.org/10.5755/j01.ee.22.5.968

David, F. R. (2011). Strategic management: concepts and cases. Boston: Prentice Hall.

Kim, W. \& Mauborgne, R. (2002, June). Charting Your Company's Future. Harvard Business Review, 5-11.

Kim, W. C. \& Mauborgne, R. (2005a). Blue Ocean Strategy: How to Create Uncontested Market Space and Make Competition Irrelevant. Boston, Massachusetts: Harvard Business School Press.

Kim, W. \& Mauborgne, R. (2005b). Value innovation: a leap into the blue ocean. Journal of Business Strategy, 26(4), 22-28. http://dx.doi.org/10.1108/02756660510608521

Kim, W. \& Mauborgne, R. (2014, May). Blue ocean leadership. Harvard Business Review, 61-68.

Milev, S. (2010). Strategicheski resheniya za klasternobazirano inovativno razvitie na industriya (po primera na trikotazhnoto proizvodstvo $v R$ Bulgaria). (Doctoral dissertation (unpublished), University of Ruse). (In Bulgarian).

Mislyashki, B. (2010). Metodika za formulirane na strategiya "Sin ocean". Avangardni nauchni instrumenti v upravlenieto, UNWE - Sofia, 3, 410417. (In Bulgarian).

Todorov, K. A. (2011). Biznes predpriemachestvo, vol. II. Sofia: BAMDE. (in Bulgarian).

Papazov, E. \& Mihaylova, L. (2009). Adapting the growth-share model for planning purposes in SMEs. The Annals of "Eftimie Murgu" University Fascicle Economic studies, 4(1), 268-276.

Papazov, E. \& Mihaylova, L. (2010). Information Provision for Strategic Planning in Bulgarian SMEs. Review of international comparative management, 11(4), 575-581. http://www.rmci.ase.ro/no11vol4/Vol11_No4_Article3.pdf

Papazov, E. \& Mihaylova, L. (2011). Produktovata diversifikatsiya v MSP kato antikrizisna reaktsiya. Journal "Izvestiya na Ikonomicheski universitet Varna”, 2, 122-127. (In Bulgarian).

Papazov, E. K. (2012). Strategic management. Ruse: Avangard print. (in Bulgarian).

Papazov, E. \& Mihaylova, L. (2012a). Vazmozhnosti za izpolzvane na matrichni modeli za nuzhdite na strategicheskiya controlling $v$ MSP. Proceedings of IX International Scientific Conference „Management of innovation - enterprises, banks, universities”, APIUI, Varna, 2012. (In Bulgarian).

Papazov, E. \& Mihaylova, L. (2012b). Using systematic planning tools for strategy rethinking of SMEs in hard times. The Annals of "Eftimie Murgu" University - Fascicle Economic studies, 7(1), 427-438.

Papazov, K. \& Milev, S. (2005). Konkurentnost chrez osvobozhdavane na ostareli strukturi i nachin na mislene. Ikonomika, 4, 12-18. (In Bulgarian).

Siegemund, C. (2008). Blue Ocean Strategy for Small and Mid-sized Companies in Germany - Development of a Consulting Approach. Hamburg: Druck Diplomica Verlag GmbH.

Sheehan, N. \& Vaidyanathan, G. (2009). Using a value creation compass to discover "Blue Oceans". Strategy \& Leadership, 37(2), 13-20. http://dx.doi.org/10.1108/10878570910941172

Zafirova, Tz. J. (2008). Strategichesko upravlenie. Varna: Nauka i Ikonomika. (In Bulgarian).

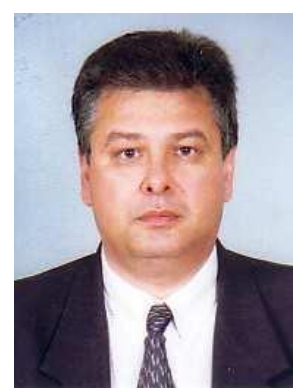

Emil Papazov obtained M. sc. ing. degree from Martin Luther University (Germany). He has a $\mathrm{PhD}$ degree in Economics. Dr. Papazov has specialized economics in Germany (at TUHannover) and management in the USA (at Cornell University).

He has also gained practical experience working for different organisations, such as Microprocessor Systems JSC, Armimex JSC and Ministry of Commerce. Now Dr. Papazov is an Associate Professor at the University of National and World Economy, Sofia. $\mathrm{He}$ is also lecturing at the University of Ruse, Bulgaria. His teaching activity is focused on business entrepreneurship and corporate strategic management.

He attended the prestigious European Entrepreneurship Colloquium in 2013, 2014 and 2015.

Address: University of National and World Economy - Sofia, Bulgaria

E-mail: epapazov@gmail.com

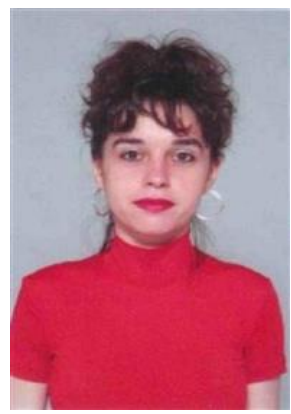

Lyudmila Mihaylova obtained M. sc. ing. degree in Accounting and Controlling from the University of Economics (Varna, Bulgaria) and Dr. sc. ing. degree in Economics from the University of Ruse (Bulgaria).

She has gained practical experience in the field of accounting and control and auditing. She has specialized in family business management in Germany, Turkey, etc. Dr. Mihaylova is now an Associate Professor at the University of Ruse.

She attended the prestigious European Entrepreneurship Colloquium in 2013, 2014 and 2015.

Address: University of Ruse "Angel Kanchev", Bulgaria

E-mail: lmihaylova777@gmail.com 